\title{
NO POLYMORPHISMS IN THE CODING REGION OF THE PRION-LIKE PROTEIN GENE IN THOROUGHBRED RACEHORSES
}

\author{
Min-Ju JEONG ${ }^{1,2}$ and Byung-Hoon JEONG ${ }^{1,2^{*}}$ \\ ${ }^{1}$ Korea Zoonosis Research Institute, Chonbuk National University, 820-120 Hana-ro, \\ Iksan, Jeonbuk 54531, Republic of Korea; ${ }^{2}$ Department of Bioactive Material Sciences, \\ Chonbuk National University, Jeonju, Jeonbuk, Republic of Korea
}

(Received 21 February 2019; accepted 2 May 2019)

\begin{abstract}
Prion diseases are fatal neurodegenerative diseases characterised by the accumulation of an abnormal prion protein isoform $\left(\mathrm{PrP}^{\mathrm{Sc}}\right)$, which is converted from the normal prion protein $\left(\mathrm{PrP}^{\mathrm{C}}\right)$. Prion diseases have been reported in an extensive number of species but not in horses up to now; therefore, horses are known to be a species resistant to prion diseases. The prion-like protein gene $(P R N D)$ is closely located downstream of the prion protein gene $(P R N P)$ and the prion-like protein (Doppel) is a homologue with PrP. Previous studies have shown that an association between prion diseases and polymorphisms of the PRND gene is reported in the main hosts of prion diseases. Hence, we examined the genetic variations of the PRND gene in Thoroughbred horses. Interestingly, polymorphisms of the $P R N D$ gene were not detected. In addition, we conducted a comparative analysis of the amino acid sequences of the PRND gene to identify the differences between horses and other species. The amino acid sequence of the horse PRND gene showed the highest identity to that of sheep $(83.7 \%)$, followed by that of goats, cattle and humans. To the best of our knowledge, this is the first genetic study of the PRND gene in horses.
\end{abstract} sistance

Key words: Horses, prion, PRND, polymorphisms, Thoroughbred, re-

Prion diseases are rare, but they are lethal neurodegenerative disorders that include Creutzfeldt-Jakob disease (CJD) in humans, scrapie in sheep and goats, bovine spongiform encephalopathy (BSE) in cattle, and chronic wasting disease (CWD) in deer (Prusiner, 1998; Williams, 2005; Goldmann, 2008; Jeong and Kim, 2014; Curcio et al., 2016). Although there is a wide spectrum of hosts involved in prion diseases, there have been no reports of prion diseases occurring in horses to date.

*Corresponding author; E-mail: bhjeong@jbnu.ac.kr; Phone: 0082 (63) 900-4040; Fax: 0082 (63) 900-4012 
Horses as well as dogs and chickens are known to be resistant to prion diseases (Perez et al., 2010; Moore et al., 2011; Zhang, 2011; Zhang et al., 2013; Qing et al., 2014; Kim et al., 2018), even though horses have a long lifespan of approximately 30 years (Perez et al., 2010). Previous studies have tried to find a specific factor to bestow the resistance of prion diseases in horses, and many researchers have focused on the structure of the prion protein ( $\mathrm{PrP})$ and its stability in horses because prion diseases are caused by the accumulation of abnormal prion protein $\left(\operatorname{PrP}^{\mathrm{Sc}}\right)$, the misfolded form of normal prion protein $\left(\operatorname{PrP}^{\mathrm{C}}\right)$. In addition, the polymorphisms of the prion protein gene (PRNP), which encodes PrP, could affect the structure and stability of $\operatorname{PrP}$ and are known to be associated with susceptibility to prion diseases (Jeong et al., 2005c, $d$; Kurt et al., 2014).

The prion-like protein gene (PRND) is located $20 \mathrm{~kb}$ downstream of the $P R N P$ gene, and the prion-like protein (Doppel) shares significant biochemical and structural homology with PrP (Moore et al., 1999; Jeong et al., 2005a). The distribution of polymorphism at the $3^{\prime}$ untranslated region (UTR) +28 site of the human PRND gene has shown significant differences between sporadic CJD and healthy control subjects (Croes et al., 2004; Jeong et al., 2005a, $b$ ). In cattle, statistical analysis of BSE-affected and healthy animals indicated that the genotype distributions of codons 95 and 132 in the bovine PRND gene are significantly different in Fleckvieh breeds (Balbus et al., 2005). In addition, recently it has been reported that the genotype of codon 26 of the ovine PRND gene is significantly linked to the disease-associated haplotype of the ovine PRNP gene and affects sperm capacitation and fertilisation ability in rams (Pereira et al., 2009; Mesquita et al., 2010). In horses, polymorphisms of the PRNP gene have been reported (Kim and Jeong, 2018b); however, polymorphisms of candidate genes related to prion disease have not been investigated thus far.

In this study, we investigated single nucleotide polymorphisms (SNPs) within the open reading frame (ORF) of the PRND gene in 242 Thoroughbred horses. In addition, we compared the amino acid sequences of the PRND gene between horses and several other species.

\section{Materials and methods}

\section{Ethical statement}

All blood samples of 242 Thoroughbred horses were provided by the Seoul Race Park in South Korea. All experimental procedures were approved by the Chonbuk National University Institutional Animal Care and Use Committee (Korea) (CBNU 2016-65). 


\section{Genetic analysis of the PRND gene}

The DNA Blood Mini Kit (Qiagen, Valencia, CA, USA) was used to isolate genomic DNA from $200 \mu \mathrm{l}$ of peripheral whole blood following the manufacturer's instructions. Polymerase chain reaction (PCR) was performed using the following gene-specific forward and reverse primers: PRND-F (5'-GCCCGT TGCAGCTTCTTATCT-3') and PRND-R (5'-GCTGGAGGAGAGAAGTGG GAT-3'). The PCR mixture comprised $2.5 \mu$ of $10 \times$ Taq DNA polymerase buffer, $0.5 \mu 1$ of $10 \mathrm{mM}$ dNTP mixture, $1 \mu \mathrm{l}$ each of forward and reverse primers, $2.5 \mu 1$ of $5 \times$ Band Helper, $0.2 \mu \mathrm{l}$ of Taq DNA polymerase (Promega, Fitchburg, WI, USA), $1 \mu$ of genomic DNA and sterile water to reach the final volume of $25 \mu 1$. PCR was conducted in an S-1000 Thermal Cycler (Bio-Rad, Hercules, CA, USA), and the PCR cycling parameters were as follows: $95^{\circ} \mathrm{C}$ for $2 \mathrm{~min}$, followed by 32 cycles of $95^{\circ} \mathrm{C}$ for $20 \mathrm{sec}, 61^{\circ} \mathrm{C}$ for $40 \mathrm{sec}, 72^{\circ} \mathrm{C}$ for $1 \mathrm{~min}$, and then 1 cycle of $72{ }^{\circ} \mathrm{C}$ for $5 \mathrm{~min}$ for the final extension. Amplified PCR products were purified by means of the Gel Extraction Kit (Qiagen) and were sequenced with an ABI PRISM 3730XL Analyzer (ABI, Foster City, CA, USA). The sequencing result was decoded using Finch TV software (Geospiza Inc., Seattle, WA, USA) and genotyping was performed.

\section{Comparison of the amino acid sequence of the PRND gene}

Sequence alignment was performed using ClustalW2 (https://www.ebi. ac.uk/Tools/msa/clustalo/). The amino acid sequences of the PRND gene, including humans (Homo sapiens, NC_000020.11), cattle (Bos taurus, AC_000170.1), sheep (Ovis aries, NC_019470.2), and goats (Capra hircus, NC_030820.1), except for horses (Equus caballus, in this study), were acquired from GenBank at the National Center for Biotechnology Information (NCBI) website.

\section{Results}

We amplified the 868 bp targeting the ORF region of the $P R N D$ gene in 242 Thoroughbred horses and performed automatic direct sequencing on the fragments. Interestingly, no polymorphisms were detected in the ORF region of the horse PRND gene (Fig. 1).

In addition, we compared the results from horses with the distributions of the PRND polymorphisms reported previously in humans, sheep, goats, and cattle. At least two or more polymorphisms in the ORF of the PRND gene were reported in several animal species except horses (Table 1). Next, we performed multiple sequence alignments among various species using ClustalW2. The amino acid sequence of the $P R N D$ gene in horses was similar to that in sheep with the highest homology $(83.7 \%)$, followed by that in goats $(83.1 \%)$, cattle $(82.6 \%)$ and humans (75.3\%) (Fig. 2). 


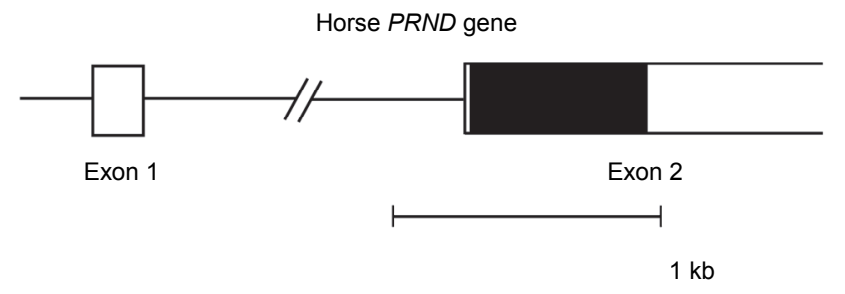

Fig. 1. Genomic map of the prion-like protein gene $(P R N D)$ in horses. Schematic diagram denotes the genomic structure of the horse $P R N D$ gene, drawn to scale. The open reading frame (ORF) within exon 2 is indicated by the black block, and white blocks indicate the 5' and 3' untranslated regions (UTRs). The edged horizontal bar indicates the regions sequenced. No polymorphisms of the PRND gene in Thoroughbred horses were found in this study

Table 1

Distribution of polymorphisms at the open reading frame (ORF) of the prion-like protein gene $(P R N D)$ in various species

\begin{tabular}{|c|c|c|c|}
\hline Species & Polymorphisms & Total, $\mathrm{n}$ & Reference \\
\hline Humans & $\begin{array}{l}\text { p.Thr26Met (T26M) } \\
\text { p.Pro56Leu (P56L) } \\
\text { p.Thr174Met (T174M) }\end{array}$ & 3 & $\begin{array}{l}\text { Peoc'h et al., 2000; } \\
\text { Jeong et al., 2005b }\end{array}$ \\
\hline Cattle & $\begin{array}{l}\text { p.Arg50His (R50H) } \\
\text { p.Ser95Ser (S95S) } \\
\text { p.Asn110His (N110H) } \\
\text { p.Arg132Gln (R132Q) } \\
\text { p.Ile176Ile (I176I) }\end{array}$ & 5 & $\begin{array}{l}\text { Comincini et al., 2001; } \\
\text { Balbus et al., 2005; } \\
\text { Kim and Jeong, 2018a }\end{array}$ \\
\hline Sheep & $\begin{array}{l}\text { p.Ile12Ile (I12I) } \\
\text { p.Ala26Ala (A26A) }\end{array}$ & 2 & $\begin{array}{l}\text { Comincini et al., 2001; } \\
\quad \text { Pereira et al., } 2009\end{array}$ \\
\hline Goats & $\begin{array}{l}\text { p.Leu10Leu (L10L) } \\
\text { p.Ser22Phe (S22F) } \\
\text { p.Ile33Ile (I33I) } \\
\text { p.Thr51Ala (T51A) } \\
\text { p.Val129Leu (V129L) } \\
\text { p.Glu96Lys (E96K) }\end{array}$ & 6 & $\begin{array}{l}\text { Uboldi et al., 2005; } \\
\text { Jeong et al., } 2018\end{array}$ \\
\hline Horses & $\mathrm{ND}^{*}$ & 0 & This study \\
\hline
\end{tabular}

*ND: not detected

\section{Discussion}

In previous studies, many researchers have reported that salt bridges and the $\beta 2-\alpha 2$ loop in the horse PRNP gene particularly provide structural stability so that horses can exhibit low susceptibility to prion disease (Perez et al., 2010; Zhang, 2011; Kurt et al., 2014). They revealed that salt bridges of the horse PrP 


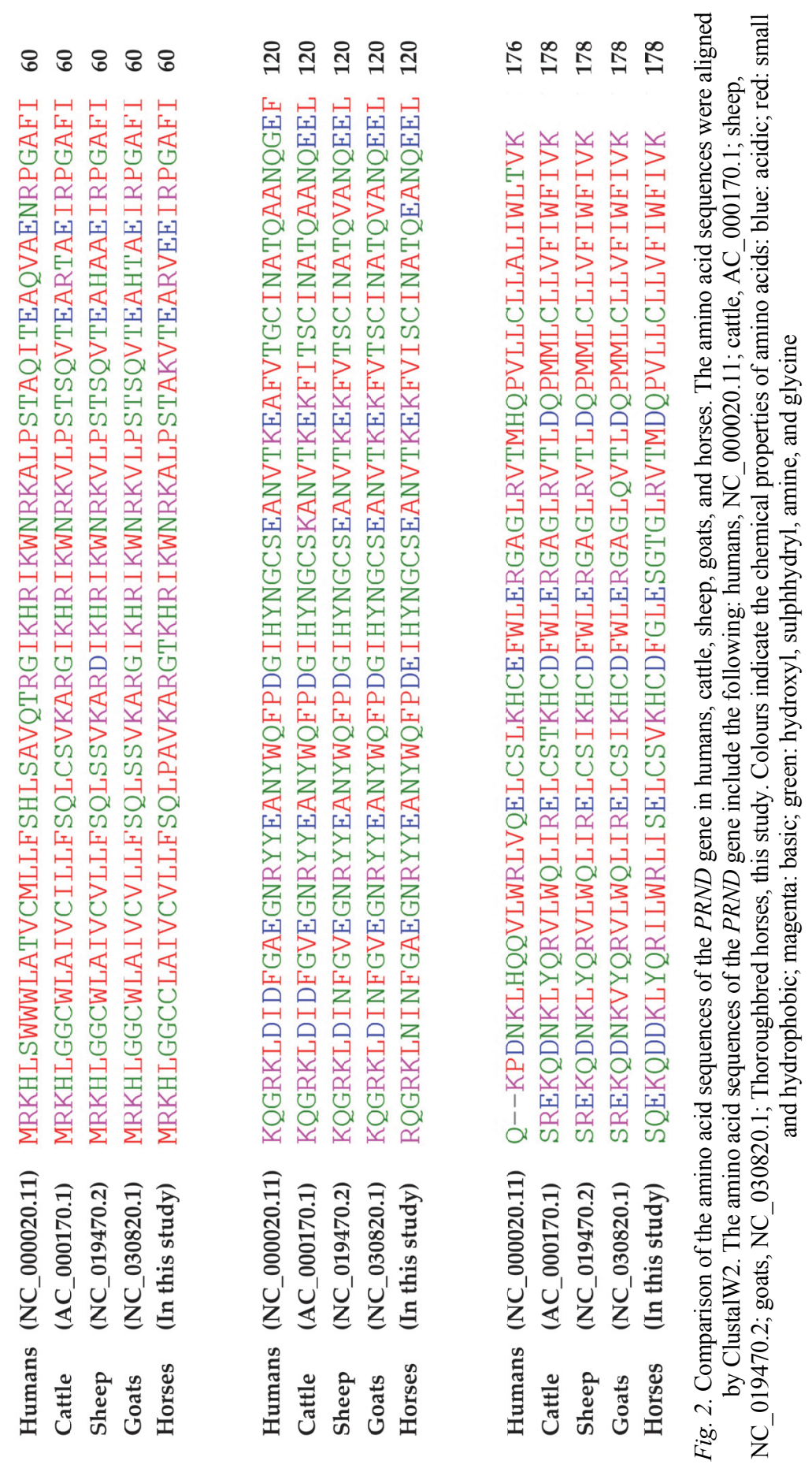


can contribute to the maintenance of a stable molecular structure in a disordered environment by linking the structure of $\beta 2$-sheet and $\alpha 2$-helix (Zhang, 2011). In addition, an amino acid alteration of the PRNP codon 167 from aspartic acid, which was conserved in various mammals, to serine, was only identified in horses and resulted in a well-defined structure of the $\beta 2-\alpha 2$ loop, consequently presenting a noteworthy stability of the horse PrP (Perez et al., 2010; SanchezGarcia and Fernandez-Funez, 2018). Nevertheless, it is still proposed that further work should be conducted in horses.

To identify the disease-related polymorphisms in various species, we tried to study the prion protein gene family, including $P R N P, P R N D$ and prion-related protein (PRNT) genes (Jeong et al., 2005d; Jeong et al., 2013; Kim and Jeong, 2017a,b; Jeong et al., 2018; Kim and Jeong, 2018a,b,c; Kim et al., 2018; Won et al., 2019). In previous studies, we found only two insertion and deletion polymorphisms in the chicken PRNP gene and one SNP in the horse PRNP gene (Kim and Jeong, 2018b; Kim et al., 2018). In this study, polymorphisms were not found in the ORF of the horse PRND gene (Fig. 1). Considering that the amino acid sequence of the $P R N D$ gene in horses was quite conserved in comparison with that in other species (Fig. 2), the absence of polymorphisms in the PRND gene is an unusual finding, which is first confirmed in Thoroughbred horses (Table 1). Therefore, it is necessary to investigate the genetic characteristics of the $P R N D$ gene in horse breeds other than the Thoroughbred in the future.

Among the various breeds of horses, Thoroughbred horses are known to be a preferable and valuable breed in the horse racing industry and have been selectively bred to nurture the outstanding qualities of racehorses (Lee et al., 2014). It is unclear whether the polymorphism of the horse PRND gene was not found in this study due to inbreeding for the preservation of the Thoroughbred lineage. However, many polymorphisms of the candidate genes related to race performance have been reported in Thoroughbred horses (Gu et al., 2010; Hill et al., 2010). In addition, the registered Thoroughbred racehorses in Seoul Race Park originated from over 10 pedigrees and 9 countries including New Zealand, the USA, Ireland, England, Japan, Canada, France, Australia, and Korea. Furthermore, the major portion of racehorses in Seoul Race Park has a low proximity coefficient of inbreeding $(\sim 0-0.2)$. It is implied that a variable genetic background exists in Thoroughbreds registered in Seoul Race Park. Since the total number of Thoroughbred racehorses raised in Korea is 16,854, the randomly selected 242 Thoroughbred samples in this study can represent the Thoroughbred population raised in Korea. In a previous study, a lot of SNPs in Thoroughbred samples obtained from Seoul Race Park have been identified using nextgeneration sequencing (Moon et al., 2015). Thus, it is estimated that the absence of PRND SNPs in Thoroughbred horses was not due to inbred status or small sample size; rather, it is a notable genetic feature of the horse, an animal resistant to prion disease. In this regard, further studies are needed to determine whether 
the rare occurrence of polymorphisms in the $P R N D$ and $P R N P$ genes has a significant effect on prion disease susceptibility.

In summary, we investigated the polymorphisms of the $P R N D$ gene in 242 Thoroughbred horses and carried out a comparative analysis of the PRND gene between horses and several other species. The amino acid sequences of the $P R N D$ gene were closely similar between the diverse species; however, polymorphisms in the ORF of the horse PRND gene were not detected. To the best of our knowledge, this study is the first genetic report of the $P R N D$ gene in horses.

\section{Acknowledgements}

This research was supported by the Basic Science Program through the National Research Foundation of Korea (NRF) funded by the Ministry of Education, Science and Technology (2015R1D1A1A01059945, 2017R1A6A1A03015876, 2018R1D1A1B070 48711). We are thankful to Mr Yong-Chan Kim for his valuable help. Min-Ju Jeong was supported by the BK21 Plus program in the Department of Bioactive Material Sciences.

\section{References}

Balbus, N., Humeny, A., Kashkevich, K., Henz, I., Fischer, C., Becker, C. M. and Schiebel, K. (2005): DNA polymorphisms of the prion doppel gene region in four different German cattle breeds and cows tested positive for bovine spongiform encephalopathy. Mamm. Genome 16, 884-892.

Comincini, S., Foti, M. G., Tranulis, M. A., Hills, D., Di Guardo, G., Vaccari, G., Williams, J. L., Harbitz, I. and Ferretti, L. (2001): Genomic organization, comparative analysis, and genetic polymorphisms of the bovine and ovine prion Doppel genes (PRND). Mamm. Genome 12, 729-733.

Croes, E. A., Alizadeh, B. Z., Bertoli-Avella, A. M., Rademaker, T., Vergeer-Drop, J., Dermaut, B., Houwing-Duistermaat, J. J., Wientjens, D. P., Hofman, A., Van Broeckhoven, C. and van Duijn, C. M. (2004): Polymorphisms in the prion protein gene and in the doppel gene increase susceptibility for Creutzfeldt-Jakob disease. Eur. J. Hum. Genet. 12, 389-394.

Curcio, L., Sebastiani, C., Di Lorenzo, P., Lasagna, E. and Biagetti, M. (2016): Review: A review on classical and atypical scrapie in caprine: Prion protein gene polymorphisms and their role in the disease. Animal 10, 1585-1593.

Goldmann, W. (2008): PrP genetics in ruminant transmissible spongiform encephalopathies. Vet. Res. 39, 30.

Gu, J., MacHugh, D. E., McGivney, B. A., Park, S. D., Katz, L. M. and Hill, E. W. (2010): Association of sequence variants in CKM (creatine kinase, muscle) and COX4I2 (cytochrome c oxidase, subunit 4, isoform 2) genes with racing performance in Thoroughbred horses. Equine Vet. J. Suppl. 38, 569-575.

Hill, E. W., Gu, J., McGivney, B. A. and MacHugh, D. E. (2010): Targets of selection in the Thoroughbred genome contain exercise-relevant gene SNPs associated with elite racecourse performance. Anim. Genet. 41, Suppl. 2, 56-63.

Jeong, B. H. and Kim, Y. S. (2014): Genetic studies in human prion diseases. J. Korean Med. Sci. 29, 623-632. 
Jeong, B. H., Jin, H. T., Carp, R. I. and Kim, Y. S. (2013): Bovine spongiform encephalopathy (BSE)-associated polymorphisms of the prion protein (PRNP) gene in Korean native cattle. Anim. Genet. 44, 356-357.

Jeong, B. H., Kim, N. H., Choi, E. K., Lee, C., Song, Y. H., Kim, J. I., Carp, R. I. and Kim, Y. S. (2005a): Polymorphism at 3' UTR +28 of the prion-like protein gene is associated with sporadic Creutzfeldt-Jakob disease. Eur. J. Hum. Genet. 13, 1094-1097.

Jeong, B. H., Kim, N. H., Kim, J. I., Carp, R. I. and Kim, Y. S. (2005b): Polymorphisms at codons 56 and 174 of the prion-like protein gene $(P R N D)$ are not associated with sporadic Creutzfeldt-Jakob disease. J. Hum. Genet. 50, 311-314.

Jeong, B. H., Lee, K. H., Kim, N. H., Jin, J. K., Kim, J. I., Carp, R. I. and Kim, Y. S. (2005c): Association of sporadic Creutzfeldt-Jakob disease with homozygous genotypes at PRNP codons 129 and 219 in the Korean population. Neurogenetics 6, 229-232.

Jeong, B. H., Sohn, H. J., Lee, J. O., Kim, N. H., Kim, J. I., Lee, S. Y., Cho, I. S., Joo, Y. S., Carp, R. I. and Kim, Y. S. $(2005 d)$ : Polymorphisms of the prion protein gene (PRNP) in Hanwoo (Bos taurus coreanae) and Holstein cattle. Genes Genet. Syst. 80, 303-308.

Jeong, M. J., Kim, Y. C. and Jeong, B. H. (2018): Prion-like protein gene (PRND) polymorphisms associated with scrapie susceptibility in Korean native black goats. PLoS One 13, e0206209.

Kim, Y. C. and Jeong, B. H. (2017a): Lack of germline mutation at codon 211 of the prion protein gene $(P R N P)$ in Korean native cattle. Acta Vet. Hung. 65, 147-152.

Kim, Y. C. and Jeong, B. H. (2017b): The first report of prion-related protein gene $(P R N P)$ polymorphisms in goat. Acta Vet. Hung. 65, 291-300.

Kim, Y. C. and Jeong, B. H. (2018a): Bovine spongiform encephalopathy (BSE) associated polymorphisms of the prion-like protein gene $(P R N D)$ in Korean dairy cattle and Hanwoo. J. Dairy Res. 85, 7-11.

Kim, Y. C. and Jeong, B. H. (2018b): The first report of polymorphisms and genetic characteristics of the prion protein gene $(P R N P)$ in horses. Prion 12, 245-252.

Kim, Y. C. and Jeong, B. H. (2018c): First report of prion-related protein gene (PRNT) polymorphisms in cattle. Vet. Rec. 182, 717.

Kim, Y. C., Jeong, M. J. and Jeong, B. H. (2018): The first report of genetic variations in the chicken prion protein gene. Prion 12, 197-203.

Kurt, T. D., Bett, C., Fernandez-Borges, N., Joshi-Barr, S., Hornemann, S., Rulicke, T., Castilla, J., Wuthrich, K., Aguzzi, A. and Sigurdson, C. J. (2014): Prion transmission prevented by modifying the beta2-alpha2 loop structure of host PrPC. J. Neurosci. 34, 1022-1027.

Lee, J. H., Lee, T., Lee, H. K., Cho, B. W., Shin, D. H., Do, K. T., Sung, S., Kwak, W., Kim, H. J., Kim, H., Cho, S. and Park, K. D. (2014): Thoroughbred horse single nucleotide polymorphism and expression database: HSDB. Asian-Australas. J. Anim. Sci. 27, 1236-1243.

Mesquita, P., Batista, M., Marques, M. R., Santos, I. C., Pimenta, J., Silva Pereira, M., Carolino, I., Santos Silva, F., Oliveira Sousa, M. C., Gama, L. T., Fontes, C. M., Horta, A. E., Prates, J. A. and Pereira, R. M. (2010): Prion-like Doppel gene polymorphisms and scrapie susceptibility in Portuguese sheep breeds. Anim. Genet. 41, 311-314.

Moon, S., Lee, J. W., Shin, D., Shin, K. Y., Kim, J., Choi, I. Y., Kim, J. and Kim, H. (2015): A genome-wide scan for selective sweeps in racing horses. Asian-Australas. J. Anim. Sci. 28, $1525-1531$

Moore, J., Hawkins, S. A., Austin, A. R., Konold, T., Green, R. B., Blamire, I. W., Dexter, I., Stack, M. J., Chaplin, M. J., Langeveld, J. P., Simmons, M. M., Spencer, Y. I., Webb, P. R., Dawson, M. and Wells, G. A. (2011): Studies of the transmissibility of the agent of bovine spongiform encephalopathy to the domestic chicken. BMC Res. Notes 4, 501.

Moore, R. C., Lee, I. Y., Silverman, G. L., Harrison, P. M., Strome, R., Heinrich, C., Karunaratne, A., Pasternak, S. H., Chishti, M. A., Liang, Y., Mastrangelo, P., Wang, K., Smit, A. F., Katamine, S., Carlson, G. A., Cohen, F. E., Prusiner, S. B., Melton, D. W., Tremblay, P., 
Hood, L. E. and Westaway, D. (1999): Ataxia in prion protein (PrP)-deficient mice is associated with upregulation of the novel PrP-like protein doppel. J. Mol. Biol. 292, 797-817.

Peoc'h, K., Guerin, C., Brandel, J. P., Launay, J. M. and Laplanche, J. L. (2000): First report of polymorphisms in the prion-like protein gene (PRND): implications for human prion diseases. Neurosci. Lett. 286, 144-148.

Pereira, R. M., Mesquita, P., Batista, M., Baptista, M. C., Barbas, J. P., Pimenta, J., Santos, I. C., Marques, M. R., Vasques, M. I., Silva Pereira, M., Santos Silva, F., Oliveira Sousa, M. C., Fontes, C. M., Horta, A. E., Prates, J. A. and Marques, C. C. (2009): Doppel gene polymorphisms in Portuguese sheep breeds: insights on ram fertility. Anim. Reprod. Sci. 114, $157-166$.

Perez, D. R., Damberger, F. F. and Wuthrich, K. (2010): Horse prion protein NMR structure and comparisons with related variants of the mouse prion protein. J. Mol. Biol. 400, 121-128.

Prusiner, S. B. (1998): Prions. Proc. Natl Acad. Sci. U. S. A. 95, 13363-13383.

Qing, L. L., Zhao, H. and Liu, L. L. (2014): Progress on low susceptibility mechanisms of transmissible spongiform encephalopathies. Dongwuxue Yanjiu 35, 436-445.

Sanchez-Garcia, J. and Fernandez-Funez, P. (2018): D159 and S167 are protective residues in the prion protein from dog and horse, two prion-resistant animals. Neurobiol. Dis. 119, 1-12.

Uboldi, C., Del Vecchio, I., Foti, M. G., Azzalin, A., Paulis, M., Raimondi, E., Vaccari, G., Agrimi, U., Di Guardo, G., Comincini, S. and Ferretti, L. (2005): Prion-like Doppel gene (PRND) in the goat: genomic structure, cDNA, and polymorphisms. Mamm. Genome 16, 963-971.

Williams, E. S. (2005): Chronic wasting disease. Vet. Pathol. 42, 530-549.

Won, S. Y., Kim, Y. C., Kim, K., Kim, A. D. and Jeong, B. H. (2019): The first report of polymorphisms and genetic features of the prion-like protein gene (PRND) in a prion diseaseresistant animal, dog. Int. J. Mol. Sci. 20, 1404.

Zhang, J. (2011): The structural stability of wild-type horse prion protein. J. Biomol. Struct. Dyn. 29, 369-377.

Zhang, Z., Wang, R., Xu, L., Yuan, F., Zhou, X., Yang, L., Yin, X., Xu, B. and Zhao, D. (2013): Molecular cloning and sequence analysis of prion protein gene in Xiji donkey in China. Gene 529, 345-350. 